\title{
Clearance Sale - A Spark Plug for Sales in Online Shopping: an Empirical Study in Bangalore City
}

\author{
Murali.S
}

\begin{abstract}
Online shopping is the need of the hour. Customer shopping online has become common. The product from less expensive to highly expensive is shopped online. This study is undertaken to assess the implications of regular online shopping after experiencing clearance sale offered by online marketers. In order to arrive at the conclusion that clearance sale is a real catalyst to convert respondents into regular online shoppers; the survey is conducted by the researcher in Bangalore City with the total sample size of 134. The Questionnaire was tailor - made to meet the objectives of the study. The close-ended questionnaire helped to get a clear idea about the consumer's attitude. The sources of data were gathered from primary and secondary data namely journals, magazines, and related websites. The majority of the consumers preferred online shopping for personal purpose and 83 percent of the respondents opine that they involve in rigorous sale during a clearance sale and also they have become regular shoppers. However, few of them stands aside by vouching that the reaction is normal during all the time and few adopt a traditional method of shopping reason out of fear of losing money when online shopping is done and local method of shopping due to the loyalty towards marketer.
\end{abstract}

Keyword: Online shopping, Customer Satisfaction, E-Payment, Delighted Customer

\section{Introduction}

E - Shopping or online shopping is a form of electronic commerce which allows consumers to directly buy goods or services from a seller over the internet using a website browser. Alternative names are e-webstore, e-shop, e-store, internet shop, web-store, online store, online storefront and virtual store. Mobile Commerce (m-commerce) describes purchasing from online retailers mobile optimized online site applications. An online shop evokes the physical analogy of buying products or services at a bricks and mortar retailer shopping center the process is called the business to customer (B2C) online shopping. In the case where a business buys from another business, the process is called the business to business (B2B) online shopping. Online shopping brings new lane to promote, advertise products and services in the market.

Online consumers are always seeking new products, new attractiveness and the most important thing being price compatibility with their budget. The internet is the best way to save time and money through purchasing online within their range of budget at home or in anywhere. Online consumers don't have limits to online shopping. They also use the internet for a comparison of prices of goods and services, news, visit social networks and search information and so on. A recent survey on the online retail sector by The Associated Chambers of Commerce and Industry of India (ASSOCHAM) has revealed that 40 percent among those surveyed across cities like the aforesaid cities namely Delhi, Mumbai, Chennai, Bangalore, Kolkata, Ahmadabad, Chandigarh, Ludhiana, Lucknow, and Jaipur revealed prefer to shop online. In fact, the inclination among the youth is going to help the online retail industry to reach Rs. 7000 Crore mark by 2015, ASSOCHAM predicts. Mumbai is one of the tops among the 5 leading cities in online shopping in India, which is set to become the third largest nation of internet users in the next two years with a large chunk of youngsters eager to adapt new technologies to rapidly changing lifestyles. The online marketers are now developing strong customer base by offering enormous products and making the whole globe as a target market. Online marketers are budding out with innovative marketing strategies to build a large customer base by attracting towards them. In the event of boosting market share, these companies are involving in offering cash offers, discounts, clearance sale, exchange offers, free home delivery, $24 \times 7$ open sales, and service. The recent event conducted by Flipkart's 'BIG BILLION DAY' is the best example to highlight this. Around 1200 Crores turnover was witnessed in one single day from Flipkart and Snapdeal online sites which was marked as the historical event in the online business in India. This study focuses on how clearance sale is acting as a catalyst for sales of online marketers. 
Clearance Sale - A Spark Plug for Sales in Online Shopping: an Empirical Study in Bangalore City

List of India's famous online shopping websites:

\begin{tabular}{|lllc|}
\hline 1. & www.flipkart.com & 10. www.amazon.in & 19. www.infibeam.com \\
\hline 2. & www.ebay.in & 11. www.snapdeal.in & 20. www.inkfruit.com \\
\hline 3. & www.shopclues.com & 12. www.shopping.indiatimes.com & 21. www.jungle.com \\
\hline 4. & www.myntra.com & 13. www.jabong.com & 22. www.bookadda.com \\
\hline 5. & www.homeshop18.in & 14. www.koovs.com & 23. www.quicker.com \\
\hline 6. & www.yebi.com & 15. www.firstcry.com & 24. www.olx.in \\
\hline 7. & www.tradus.com & 16. www.bestlish.com & \\
\hline 8. & www.pepperfry.com & 17. www.zoomin.com & \\
\hline 9. & www.futurebazar.com & 18.www.goodlife.com & \\
\hline
\end{tabular}

Above details shows a list of famous online shopping in India. Products available namely: Books and Stationery, Home Appliances, Computers, Mobiles and accessories, Clothes, Footwear, Electronics and Electricals Products with accessories, Cosmetics, Toys, Gifts, Jewellery, Furniture's etc

\section{Literature review}

Internet shopping gives a decent case of the business transformation. In China, web based business is presently encountering a time of quick advancement; the huge number of Internet clients gives a decent establishment to the extension of the web based shopping market. In this review, saw ease of use, saw security, saw protection, saw after-deals benefit, saw promoting blend, and saw notoriety were utilized for examination. This exploration was directed by utilizing the essential information source, and the overview strategy was utilized in the examination. This exploration found that there were connections between the apparent ease of use, saw security, saw protection, saw after-deals benefit, saw showcasing blend, saw notoriety and customers' mentality to embracing web based shopping in China. Nonetheless, just advertising blend and notoriety were found to essentially impact purchasers' disposition to receive web based shopping. The discoveries help us in comprehension shoppers' online buy habits.

According to Wolfinbarger and Gilly (1999), consumers make online shopping for both goal-oriented and experiential reasons, but goal-oriented motives are more common among online shoppers than are experiential motives. Greenfield Online suggested that online shoppers like to use Internet shopping because of its convenience and timesaving. This report found that convenience-oriented consumers prefer to buy on the Internet and experience-oriented consumers don't. Li et al. (1999) proposed that frequent Web buyers are higher in the convenience orientation but lower in the experiential orientations than occasional Web buyers and no differences were assumed in the recreational orientation and the economy orientation. Bellenger and Korgaonkar (1980) suggest that consumers can be categorized into two types: recreational and convenience shoppers. They proposed that the social aspect of shopping motivates the recreational shopper. Some research proposed that online shopping is not attractive to consumers who prefer to social interaction or experience. Swaminathan, Lepkowska-White, and Rao (1999) found that consumers who are oriented to convenience is more likely to use the Internet to buy goods and consumers who value social interaction is less likely to use the Internet for shopping. Through these findings, it is assumed that consumers who want convenience are more likely to purchase on the Internet than consumers who like experiencing product. Consumers who are convenience-oriented are more likely to purchase online than those who are not. Consumers who are experience-oriented are less likely to purchase online than those who are not.

Haubl, G et al, (2004), uncertainties about the products and the shopping processes, the trustworthiness of the online seller, or the convenience and economic utility they wish to derive from electronic shopping determine the costs versus the benefits of this environment for consumers and shoppers.

Khurana and Kahn et al., (2001), Online shopping features can be either consumers' perception of functional and utilitarian dimensions, like "ease of use" and "usefulness", or their perceptions of emotional and hedonic dimensions like "enjoyment".

R. K. Rajamma et al, (2008) the use of Internet is catching up and online shopping is considered as a relevant alternative channel for retailing in India, and it is now an important part of the retail experience. He has conducted an empirical study basically based on primary data but secondary data have also been collected from various sources (published and unpublished) including websites.

Zhang, $P$ et al, (2000), Investing in consumer satisfaction from the online experience and creating brand or site loyalty are critically important for companies that want to have a long run presence on the Web. There are two approaches taken to induce loyalty into consumers in an online context. One approach is to focus on concrete factors. For example, creating a convenient and well-designed online store and offering secure transactions are the keystones of satisfying e-consumers. 


\section{Objectives of the Study}

- To study the consumer preferences on clearance sale of online products and services.

- To identify the impact of media on purchasing decision of online products and services.

- To analyze the awkwardness faced by the consumers while shopping online.

\section{Research Methodology}

The data for the research purpose has gathered from both primary data and secondary data. Secondary data is collected from research articles, books, references and so on. To gather the information through primary data a closed-ended structured questionnaire was issued to 210 respondents but only 165 was received by the researcher among them 134 were useful for further analysis. The questionnaire are prepared using five-points Likert scale ranging from point 1 to 5 representing strongly agree to strongly disagree as extreme points in the attitude measurement scale.

Statistical data are analyzed using averages, percentage, ratio. The inferences are drawn using inductive principles.

\section{Hypothesis:}

H1: There is a significant relationship between Clearance sale and regular online shopping

\section{Results and Discussions:}

Table No. 1: Profile of the Respondents

\begin{tabular}{|c|c|c|c|}
\hline Sl. No. & Contents & No. of Respondents & Percentage \\
\hline \multirow[t]{6}{*}{1} & Age & & \\
\hline & $18-20$ & 29 & 21.64 \\
\hline & $21-25$ & 39 & 29.10 \\
\hline & $26-30$ & 34 & 25.38 \\
\hline & $31-40$ & 22 & 16.42 \\
\hline & $41 \&$ above & 10 & 7.46 \\
\hline \multirow[t]{3}{*}{2} & Gender & & \\
\hline & Male & 92 & 68.66 \\
\hline & Female & 42 & 31.34 \\
\hline \multirow[t]{5}{*}{3} & Profession & & \\
\hline & Business & 40 & 29.85 \\
\hline & Service (Public \& Private) & 37 & 27.61 \\
\hline & Professionals & 30 & 22.39 \\
\hline & Student & 27 & 20.15 \\
\hline \multirow[t]{6}{*}{4} & Education & & \\
\hline & Primary & 04 & 2.99 \\
\hline & SSLC & 19 & 14.18 \\
\hline & PUC & 28 & 20.90 \\
\hline & Graduate & 46 & 34.33 \\
\hline & Post Graduate \& above & 37 & 27.60 \\
\hline \multirow[t]{7}{*}{5} & Monthly Income & & \\
\hline & Less than 5,000 & 37 & 27.60 \\
\hline & $5,001-10,000$ & 13 & 9.70 \\
\hline & $10,001-15,000$ & 16 & 11.94 \\
\hline & $15,001-20,000$ & 23 & 17.17 \\
\hline & $20,001-25,000$ & 21 & 15.68 \\
\hline & $25,001 \&$ above & 24 & 17.91 \\
\hline
\end{tabular}

Source: Field Survey

Table no. 1 showing details of socio-economic profile of 134 respondents in Bangalore City, in this table it is covered information related to types of bank, age, gender, profession, education of respondents and monthly income of the respondents.

Table No. 2 Respondents visiting online shopping websites more at the time of Clearance Sale

\begin{tabular}{|l|l|l|}
\hline Response & No. of Respondents & Percentage \\
\hline Yes & 93 & 69.40 \\
\hline No & 41 & 30.60 \\
\hline
\end{tabular}

Source: Field Survey

Table no.2 showing respondents visiting online shopping and purchase of goods and services, the survey samples were only 134 respondents but 93 respondents purchase of goods and services from the online website. 
Table No. 3 Showing Respondents Buying List of Online Shopping Websites

\begin{tabular}{|l|l|l|l|}
\hline Sl. No. & Contents & No. of Respondents & Percent \\
\hline 1. & Flipkart.com & 38 & 40.86 \\
\hline 2. & Amazon. in & 08 & 08.60 \\
\hline 3. & Homeshop18.com & 16 & 17.20 \\
\hline 4. & Snapdeal.com & 16 & 17.20 \\
\hline 5. & EBay. In & 24 & 25.81 \\
\hline 6. & Myntra.com & 22 & 23.66 \\
\hline 7. & Junglee.com & 08 & 08.60 \\
\hline 8. & Bookadda.com & 15 & 16.13 \\
\hline 9. & Infibeam & 21 & 22.58 \\
\hline 10. & Jabong.com & 11 & 11.83 \\
\hline 11. & Quicker.com & 13 & 13.98 \\
\hline 12. & Olx.in & 17 & 18.28 \\
\hline 13. & Yebhi.com & 09 & 09.68 \\
\hline
\end{tabular}

Source: Field Survey

Table no.3 showing that 93 respondents visit online shopping websites. The table shows respondents choosing multiple online websites for online purchase. The majority of the respondents nearing to $40.86 \%$ intended to buy from flipkart.com, after that $23.66 \%$ respondent's buy from e-bay.in, $23.66 \%$ of respondents buying from myntra.com, $22.58 \%$ respondents from infibeam, $18.28 \%$ respondents from Olx.in, $17.20 \%$ respondents from both homeshop18.com and snapdeal.com, 16.13\% respondents from bookadda.com, $13.98 \%$ respondents from quicker.com, $11.83 \%$ respondents from jabong.com, 9.68\% respondents from yebhi.com and $8.60 \%$ respondents buying goods and services from amazon.in online website.

Table No. 4 Reasons for buying products from the internet in the Clearance sale

\begin{tabular}{|l|l|l|}
\hline Contents & No. of Respondents & Percentage \\
\hline Personal & 102 & 76.34 \\
\hline Business & 14 & 10.75 \\
\hline Both & 18 & 12.90 \\
\hline
\end{tabular}

Source: Field Survey

Table no. 4 showing that respondents use online shopping to buy personal purpose, i.e. $76.34 \%$ whereas, $10.75 \%$ use online shopping to buy business purpose and $12.90 \%$ use online shopping to buy both personal and business purpose.

Table No. 5 Showing type of products preferred from respondents by online shopping

\begin{tabular}{|l|l|l|}
\hline Sl. No. & Contents & Percentage \\
\hline 1. & Books and Stationeries & 31.19 \\
\hline 2. & Cloths & 18.28 \\
\hline 3. & Cosmetics & 17.20 \\
\hline 4. & Footwear & 22.58 \\
\hline 5. & Mobile and Accessories & 32.26 \\
\hline 6. & Laptop / Desktop and accessories & 25.80 \\
\hline 7. & Television & 04.30 \\
\hline 8. & Refrigerator & 01.08 \\
\hline 9. & Washing machine & 02.15 \\
\hline 10. & Furnitures & 01.08 \\
\hline 11. & Software & 40.86 \\
\hline 12. & Music and Movies & 21.50 \\
\hline 13. & Sports & 17.20 \\
\hline 14. & Gifts & 25.80 \\
\hline
\end{tabular}

Source: Field Survey

Table no. 5 showing type of products preferred from respondents by online shopping, whereas majority respondents are purchase software products, i.e. 40.86 and consumers more preference to buy mobile and accessories with a percentage of $32.26,31.19 \%$ of respondents are buying books and stationeries. $25.80 \%$ are buying both laptop or desktop and accessories and gifts. $22.58 \%$ respondents are purchased the product footwear. Consumer purchased $18.28 \%$ of cloths product, $17.20 \%$ of cosmetics and sports products purchase from online shopping. 
Table No. 5 Respondents use Mode of Payment

\begin{tabular}{|l|l|l|l|}
\hline Sl. No. & Contents & No. of Respondents & Percentage \\
\hline 1. & Cash on delivery & 72 & 52.69 \\
\hline 2. & Debit Card & 37 & 26.88 \\
\hline 3. & Credit Card & 14 & 10.75 \\
\hline 4. & Internet/ Mobile Banking & 11 & 07.53 \\
\hline 5. & Cheque/ Demand Draft & 02 & 02.15 \\
\hline
\end{tabular}

\section{Source: Field Survey}

Table no.5 showing respondents using mode of payment, whereas majority of $52.69 \%$ respondents buying products from the mode of payment of cash on delivery, $26.88 \%$ of respondents using debit card for purchasing products from online, $10.75 \%$ of respondents using credit card for online purchase, $7.53 \%$ of respondents using the internet or mobile banking and few of them purchase using cheque or demand draft from the online shopping.

Table No. 6 Respondents as per the factor influencing in decision to purchase goods from online

\begin{tabular}{|l|l|l|l|l|l|l|}
\hline Sl. No. & Categories & $\begin{array}{l}\text { Strongly } \\
\text { Disagree }\end{array}$ & Disagree & Neutral & Agree & $\begin{array}{l}\text { Strongly } \\
\text { Agree }\end{array}$ \\
\hline 1. & Security & 06 & 07 & 10 & 70 & 36 \\
\hline 2. & Advertisement & 07 & 08 & 20 & 70 & 29 \\
\hline 3. & Reputation of Company & 05 & 15 & 21 & 61 & 37 \\
\hline 4. & Guarantees and Warrantees & 05 & 07 & 43 & 60 & 19 \\
\hline 5. & Delivery Time & 00 & 08 & 32 & 73 & 21 \\
\hline 6. & Variety of Goods & 00 & 06 & 27 & 66 & 35 \\
\hline 7. & Good description of goods & 09 & 13 & 29 & 62 & 21 \\
\hline 8. & Goods Packing & 10 & 15 & 25 & 61 & 23 \\
\hline 9. & Service & 07 & 10 & 19 & 70 & 28 \\
\hline
\end{tabular}

Source: Field Survey

Table no.6 showing respondents as per the factor influencing in decision to purchase goods from online, whereas, respondents agree and strongly agree with the categories of security, advertisement, reputation of company, guarantees, and warranties, delivery of time, variety of goods, good description of goods, goods packing and service from all these respondents are satisfied with above different fields and very few of them are strongly disagree with goods description, guarantees, and warranties and packing except these respondents are satisfies with online shopping.

Table No. 7 represents the distribution of respondents facing problem

\begin{tabular}{|l|l|l|}
\hline No. of Times Problem Facing & No. of Respondents & Percentage \\
\hline Null & 62 & 46.24 \\
\hline 1 & 36 & 26.89 \\
\hline 2 & 21 & 16.13 \\
\hline $3-4$ & 05 & 03.23 \\
\hline 5 \& above & 00 & 00 \\
\hline
\end{tabular}

Source: Field Survey

Table no.7 showing $46.24 \%$ of the respondents reveals that they have not faced any difficulty, whereas $26.89 \%$ of the respondents have faced difficulty only once, $16.13 \%$ of respondents have faced difficulties twice, $3.23 \%$ of respondents have faced difficulties three to four times and remaining none of the respondents have faced five and above.

Table No. 8: Showing overall satisfaction with the clearance offers and services which are provided by online shopping

\begin{tabular}{|l|l|l|}
\hline Categories & No. of Respondents & Percentage \\
\hline Yes & 102 & 76.34 \\
\hline No & 03 & 02.15 \\
\hline Null & 29 & 21.51 \\
\hline
\end{tabular}

\section{Source: Field Survey}

Table no. 8 showing reveals that majority of the respondents are satisfied with the clearance sales \& services to provide online. $76.34 \%$ of the respondents are satisfied to the overall satisfaction with the services which are provided by online shopping, only $2.15 \%$ of the respondents contacted the customer service department of internet retailer with complaints and $21.15 \%$ of the respondents reveal nothing. 
Table No. 9: Clearance sale has converted you to the regular customer of online shopping and has increased a number of goods purchased.

\begin{tabular}{|l|l|l|}
\hline Categories & No. of Respondents & Percentage \\
\hline Yes & 111 & 83.24 \\
\hline No & 23 & 16.76 \\
\hline
\end{tabular}

Source: Field Survey

The above table highlights that the clearance is mooting the regular sales by the respondents. The respondents have become regular purchasers of online products and services. Evidently, 83.24 percentage of the respondents agrees on the above-said statement whereas very few respondents stay neutral. The reasons are many which include an expectation of offers and various other benefits.

\section{Hypothesis Testing Test 1: Correlation}

Table 10:

\begin{tabular}{|c|c|c|c|}
\hline & & Clearance Sale & Regular Sale \\
\hline \multirow[t]{3}{*}{ Clearance Sale } & Pearson Correlation & 1 & $.616^{* *}$ \\
\hline & Sig. (2-tailed) & & .000 \\
\hline & $\mathrm{N}$ & 134 & 134 \\
\hline \multirow[t]{3}{*}{ Regular Sale } & Pearson Correlation & $.616^{* * *}$ & 1 \\
\hline & Sig. (2-tailed) & .000 & \\
\hline & $\mathrm{N}$ & 134 & 134 \\
\hline
\end{tabular}

Table 11:

\begin{tabular}{|c|c|c|c|c|c|}
\hline \multicolumn{6}{|c|}{ Paired Samples Statistics } \\
\hline & & Mean & $\mathrm{N}$ & Std. Deviation & Std. Error Mean \\
\hline \multirow[t]{2}{*}{ Pair 1} & Clearance Sale & 1.1940 & 134 & .39694 & .03429 \\
\hline & Regular Sale & 1.3881 & 134 & .48914 & .04225 \\
\hline
\end{tabular}

Table 12:

\begin{tabular}{|c|c|c|c|c|}
\hline \multicolumn{5}{|c|}{ Paired Samples Correlations } \\
\hline & & $\mathrm{N}$ & Correlation & Sig. \\
\hline Pair 1 & $\begin{array}{l}\text { Clearance Sale \& } \\
\text { Regular Sale }\end{array}$ & 134 & .616 & .000 \\
\hline
\end{tabular}

In paired test for consumers' preference online shopping in regular sale and clearance sale has a correlation of .616 which is greater than .05. Hence, it can assume that correlation of clearance sale and regular sale is relatively equal. To test if the difference is statistically significant or not the test reveals that null hypothesis is accepted and alternate hypothesis is rejected because $\mathrm{p}>.05$ which is .616 with the significant value is .000 .

\section{Test 2: ANOVA}

Table 13:

\begin{tabular}{|l|l|l|l|l|l|}
\hline \multicolumn{9}{|l|}{ ANOVA } \\
\hline Clearance Sale & Sum of Squares & df & Mean Square & F & Sig. \\
\hline & 7.955 & 1 & 7.955 & 80.776 & .000 \\
\hline Between Groups & 13.000 & 132 & .098 & & \\
\hline Within Groups & 20.955 & 133 & & & \\
\hline Total &
\end{tabular}

From the above table no 13 it is clear that there is a variance between the variable clearance sale and regular sale hence it can be inferred that clearance sale has mooted the respondents to involve in a regular sale. This hypothesis is proved as the survey results showing majority positive opinion and test statistics supporting the same.

\section{Findings}

1. Respondents Buying from more than 10 different Online Shopping Websites in India such as the majority of the $40.86 \%$ respondents were intend to buy from flipkart.com, after that $23.66 \%$ respondent's buy from ebay.in, $23.66 \%$ of respondents buying from myntra.com, $22.58 \%$ respondents from infibeam, $18.28 \%$ respondents from Olx.in, 17.20\% respondents from both homeshop18.com and snapdeal.com, 16.13\% respondents from bookadda.com, $13.98 \%$ respondents from quicker.com, $11.83 \%$ respondents from 
jabong.com, $9.68 \%$ respondents from yebhi.com and $8.60 \%$ respondents buying goods and services from amazon.in online website.

2. $76.34 \%$ of the respondents use online shopping for personal purpose after the clearance sale offers and benefits.

3. Majority respondents are purchase software products, i.e. 40.86 and consumers more preference to buy mobile and accessories with the percentage of 32.26, 31.19\% of respondents are buy books and stationeries. $25.80 \%$ are buying both laptop or desktop and accessories and gifts. $22.58 \%$ respondents are purchased the product footwear. Consumer purchased $18.28 \%$ of cloths product, $17.20 \%$ of cosmetics and sports products purchase from online shopping.

4. majority of $52.69 \%$ respondents buying products from the mode of payment of cash on delivery, $26.88 \%$ of respondents using debit card for purchasing products from online.

5. Respondents are agreed and strongly agree with the categories of security, advertisement, the reputation of a company.

6. $46.24 \%$ of the respondents reveal that they have not faced any difficulty.

7. The majority of the respondents are satisfied with the services to provide online. $76.34 \%$ of the respondents are satisfied to the overall satisfaction with the services which are provided by online shopping.

8. Most importantly from the research, it is proved that the clearance sale offered by the online marketers has made the respondents as a regular customer for online shopping. The impact is shown in the table where 83 percent of the respondents agrees on the same.

\section{Conclusion}

Consumer preference towards Online Shopping has clearly stated that there is a significant humiliate of online shopping in a present context. In this event, people started to accept the new lifestyle. The online shopping store is a recent development in the lifestyle of the people with the moving time and the demand of the hour. The online shopping stores are significantly increasing in more number. People are hesitant to purchase costly products, but now started to shop online along with this drastic change the clearance sale has become attractive offers for the people to accept online shopping since it offers better financial benefits for the greater value of the product and their needs and wants are fulfilled to the core. Especially students are purchasing more products of fiction and nonfiction, course and various competitive exams books are purchased. Few people like to stick to their traditional and local methods. The researcher reveals people started to accept new lifestyle and also aware online shopping methods.

\section{Bibliography}

[1]. Haubl, G., and Trifts, V (2000). Consumer decision making in online shopping environments: the effects of interactive decision aids Marketing Science (19:1), 2000, pp. 4-21

[2]. Zhang, P., and von Dran, G (2001). User expectations and ranks of quality factors in different website domains,î International Journal of Electronic Commerce (6:3), pp. 9-34

[3]. Mathwich, C (2002). Understanding the online consumer: A typology of online relational norms and behavior, Journal of Interactive Marketing (16:1), pp. 40-55

[4]. Yu, J., Ha, I., Choi, M. and Rho, J. (2005) 'Extending the TAM for a t-commerce,' Information \& Management, 42 (77), 965- 976.

[5]. Verhagen, T., Meents, S. and Tan, Y. (2006) 'Perceived Risk and Trust Associated with Purchasing at Electronic Marketplaces,' in Serie Research Memoranda 0001, Faculty of Economics, Business Administration and Econometrics, Free University of Amsterdam, Amsterdam, Netherlands

[6]. Consumer E-Commerce Market in India 2006/07 - A Report by eTechnology Group@ IMRB for Internet and Mobile Association in India. E-Commerce in India. September 2007.

[7]. R. K. Rajamma, A K. Paswan \& G. Ganesh (2007). Services purchased at brick and mortar versus online stores, and shopping motivation. The Journal of Services Marketing, Vol. 21, Iss. 3, p. 200

[8]. Ahmad, Iftikhar and Aatur, Rahman, Chowdhary (2008) "Electronic Customer Relationship Management (Ecrm)" Examined Customers' Perception Of Value From Ecrm Features On Airline E-Ticketing Websites" MasterThesis. Lulea University of Technology.

[9]. Khurana, Sunayna (2009), "Managing Service Quality: An Empirical Study on Internet Banking”, The Icfai Journal of Marketing Management, Vol.VIII, No. 3-4, pp. 96-116. 